\title{
Gambaran Validitas Pemeriksaan Complex Specific Cocktail Antigen Mycobacterium tuberculosis (ESAT-6, CFP-10, MPT-64) Metode Rapid Immunochromatography pada Bahan Pemeriksaan Sputum dan Serum Penderita Tuberkulosis Paru
}

\author{
Hendra Subroto, ${ }^{1}$ Ida Parwati, ${ }^{2}$ Dewi Kartika Turbawaty, ${ }^{2}$ Bachti Alisjahbana ${ }^{3}$ \\ ${ }^{1}$ Fakultas Kedokteran Universitas Maranatha Bandung, ${ }^{2}$ Departemen Patologi Klinik Fakultas Kedokteran \\ Universitas Padjadjaran/Rumah Sakit Umum Pusat Dr. Hasan Sadikin Bandung, ${ }^{3}$ Departemen Ilmu Penyakit \\ Dalam Fakultas Kedokteran Universitas Padjadjaran/Rumah Sakit Umum Pusat Dr. Hasan Sadikin Bandung
}

\begin{abstract}
Abstrak
Penegakan diagnosis tuberkulosis (TB) paru penting dalam mengurangi morbiditas dan mortalitas. Diagnosis laboratorium TB paru berdasar atas pemeriksaan BTA dan kultur M. tuberculosis memiliki sensitivitas rendah. Terdapat pemeriksaan cocktail antigen TB rapid immunochromatography (ICT) yang mendeteksi antigen ESAT-6, CFP-10, MPT-64 yang disekresikan oleh M. tuberculosis. Tujuan penelitian menganalisis validitas pemeriksaan cocktail antigen TB metode rapid ICT sputum dan serum penderita TB paru terhadap kultur Ogawa. Penelitian dilaksanakan Juli-Oktober 2014 di RSUP Dr. Hasan Sadikin Bandung. Bentuk penelitian adalah observasional deskriptif khusus dengan rancangan penelitian potong lintang. Subjek penelitian penderita yang datang ke Poliklinik Pulmonologi atau Poliklinik DOTS, didiagnosis TB paru. Sebanyak 68 sputum dan serum dari 33 kultur sputum M. tuberculosis positif dan 35 kultur negatif dilakukan pemeriksaan cocktail antigen TB rapid ICT. Angka positivitas cocktail antigen TB rapid ICT sputum 54,4\%; serum tanpa pemanasan 0\%. Pada serum dilakukan pemanasan pada suhu $56^{\circ} \mathrm{C}$ selama 30 menit untuk menghilangkan aktivitas antibodi dan didapatkan angka positivitas sebesar 19,1\%. Nilai sensitivitas dan spesifisitas pemeriksaan untuk sputum 93,9\% dan 82,8\%, untuk serum tanpa pemanasan $0 \%$ dan $100 \%$, serta serum dengan pemanasan $24,2 \%$ dan $85,7 \%$. Validitas pemeriksaan sputum memiliki sensitivitas tinggi dan spesifisitas sedang, untuk serum memiliki sensitivitas rendah dan spesifisitas tinggi. [MKB. 2017;49(3):178-85]
\end{abstract}

Kata kunci: Cocktail antigen TB rapid ICT, kultur Ogawa, mikroskopik BTA, tuberkulosis paru, serum, sputum

\section{Validity of Complex Specific Cocktail Antigen Mycobacterium tuberculosis (ESAT-6, CFP-10, MPT-64) Rapid Immunochromatography Method on Sputum and Serum Samples from Patient with Pulmonary Tuberculosis}

\begin{abstract}
Early diagnosis of pulmonary tuberculosis (TB) is very important in reducing morbidity and mortality. The current diagnosis of TB includes direct staining (acid fast bacilli) or M. tuberculosis culture, but these examinations have a low sensitivity. An assay using rapid ICT cocktail antigen TB is currently available for diagnosing TB. This method can detect ESAT-6, CFP-10, and MPT-64 antigen which is secreted by M. tuberculosis. The aim of this study was to analyze the validity of cocktail antigen TB rapid ICT using sputum and serum with Ogawa culture. This was a crosssectional descriptive observational study. Sputum and serum were collected from patients who were diagnosed as lung TB suspects in the lung and DOTS Clinic of Dr. Hasan Sadikin General Hospital Bandung during the period of July-December 2014 in . Cocktail antigen TB detection assay using two kind of samples (sputum and serum) were evaluated. A total of 68 subjects of 33 subjects presented positive culture and 35 presented negative cultures. Positivity rates for sputum and serum were $54.4 \%$ and $0 \%$, respectively. Heated sputum assay had a sensitivity of $93.9 \%$ and specificity of $82.8 \%$, Serum assay presented a sensitivity of $0 \%$ and specificity of $100 \%$. Serum were modified by heating at $560 \mathrm{C}$ for 30 minutes. The positivity rate of heated serum was $19.1 \%$. The result of modified serum assay showed a sensitivity of $24.2 \%$ and specificity of $85.7 \%$. Conclusion: the sensitivity of the sputum assay is high and the specificity is medium. The sensitivity of this serum assay is low and the specificity is high. [MKB. 2017;49(3):178-85]
\end{abstract}

Key words: Acid fast bacilli, cocktail antigen TB rapid ICT, pulmonary tuberculosis, Ogawa culture, sputum, serum

Korespondensi: Hendra Subroto, dr., SpPK., Fakultas Kedokteran Universitas Maranatha Bandung, E-mail: henzu_inter@ yahoo.co.id 


\section{Pendahuluan}

Tuberkulosis (TB) masih merupakan masalah kesehatan global yang utama. Sejak tahun 1993, World Health Organization (WHO) report menyatakan bahwa TB merupakan kedaruratan global bagi kemanusiaan. Pada tahun 2012 diperkirakan TB telah menginfeksi sepertiga populasi penduduk di dunia dengan 8,6 juta kasus baru dan menyebabkan 1,3 juta kematian. ${ }^{1}$ Tuberkulosis adalah penyebab utama kematian setelah human immunodeficiency virus (HIV) dari seluruh penyakit infeksi di dunia. ${ }^{1}$

World Health Organization (WHO) report tahun 2013 menyatakan bahwa insidensi TB di Indonesia berada pada urutan keempat paling banyak di dunia, setelah India, Cina, dan Afrika Selatan. Jumlah kasus baru basil tahan asam (BTA) positif yang ditemukan di Indonesia pada tahun 2012 sebanyak 202.301 kasus.

Tuberkulosis paru aktif merupakan penyakit infeksi saluran napas bagian bawah yang menyerang jaringan paru-paru atau parenkim paru oleh Mycobacterium tuberculosis. Infeksi TB ditularkan melalui udara (airborne) tercemar dengan droplet yang mengandung M. tuberculosis dari penderita dengan TB paru aktif yang dikeluarkan dengan cara batuk, bersin, atau percikan ludah. Individu yang terpapar akan mengalami tiga kemungkinan patogenesis. Pertama, M. tuberculosis langsung segera dieliminasi. Kedua, merupakan kejadian paling sering adalah bertahan infeksi melalui keberhasilan pembentukan granuloma yang kemudian menghasilkan infeksi TB laten. Ketiga, individu yang terinfeksi mengalami kegagalan imunitas adaptif sehingga terbentuklah infeksi primer. Proses patogenesis yang ketiga hanya terjadi pada sejumlah kecil (5-10\%) penderita. ${ }^{5}$

Pemeriksaan laboratorium untuk diagnosis dini TB paru saat ini mempunyai keterbatasan, antara lain nilai sensitivitas pada pemeriksaan mikroskopik BTA yang rendah, metode kultur yang membutuhkan waktu lama, atau metode molekuler yang memerlukan keahlian khusus. ${ }^{4}$ Metode kultur sputum merupakan metode baku emas (gold standard) untuk diagnosis TB paru. Diagnosis dini dan penangganan yang tepat penting dalam upaya mencegah penyebaran $M$. tuberculosis. ${ }^{1}$

Pemeriksaan mikroskopis BTA sudah dikembangkan lebih dari 100 tahun lalu oleh Robert Koch. Keterbatasan metode ini antara lain memerlukan sedikitnya $10^{4}$ BTA dalam 1 $\mathrm{mL}$ sputum. Hal ini yang menyebabkan hampir $50 \%$ kasus TB paru hasil BTA-nya negatif.
Selain itu, terdapat sekitar $30 \%$ penderita TB paru yang tidak dapat memproduksi sputum sehingga hasil pemeriksaan mikroskopik BTA negatif belum menyingkirkan diagnosis TB paru. ${ }^{7,8}$ Hasil pemeriksaan mikroskopik BTA yang baik sangatlah dipengaruhi oleh kualitas bahan pemeriksaan, ketebalan hapusan dan lamanya dekolorisasi, jenis kontras pewarnaan yang digunakan, dan personil laboratorium yang terlatih. Terdapat organisme non-mycobacterial yang dapat memperlihatkan gambaran seperti BTA pada pemeriksaan mikroskopik BTA, yaitu Rhodococcus, Nocardia, Legionella micdadei, kista Cryptosporodium, Isospora, Cyclospora, dan spora Microsporidium. Sensitivitas pemeriksaan mikroskopik BTA menurut beberapa penelitian bervariasi $50-60 \%$.

Diagnosis TB melalui pemeriksaan kultur memerlukan waktu lama, yaitu 6-8 minggu. Selain memerlukan waktu lama, didapatkan 5\% kemungkinan kontaminasi oleh bakteri lain meskipun sudah dilakukan dekontaminasi dengan $\mathrm{NaOH} 4 \%$. Dengan keterbatasan tersebut maka untuk memperbaiki diagnosis TB paru dan memulai inisiasi obat anti-tuberkulosis lebih cepat maka diperlukan suatu metode diagnostik yang mudah, cepat, dan lebih akurat untuk meningkatkan strategi efisiensi dalam pengendalian TB. ${ }^{8,9,11}$ Menurut Schulger di negara dengan sarana terbatas, pemeriksaan baru yang ideal untuk menunjang diagnosis adalah yang tidak memerlukan listrik, lemari pendingin, akses terhadap air bersih, mudah digunakan dengan sedikit atau tanpa pelatihan, dan hasil didapatkan dalam waktu 1 jam. Selain itu, diharapkan nilai sensitivitas dan spesifisitas $\geq 90 \%$.

Berbagai materi yang berkaitan dengan $M$. tuberculosis dapat digunakan untuk diagnostik. Materi ini antara lain asam nukleat, antigen, dan antibodi. Pada tahun 2011 WHO tidak merekomendasikan pemeriksaan imunoserologi deteksi antibodi untuk membantu diagnosis TB paru aktif karena berdasar penelitian didapatkan sensitivitas yang rendah dan bervariasi $1-60 \%$, spesifisitas 53-99\%, dan positif palsu dan negatif palsu yang tinggi. Pemeriksaan polymerase chain reaction (PCR) untuk mendeteksi asam nukleat memerlukan tempat khusus dan tenaga ahli, oleh karena itu diharapkan deteksi antigen TB dapat membantu menegakkan diagnosis TB paru terutama di daerah terpencil. ${ }^{1}$

Dalam beberapa tahun terakhir, terdapat kemajuan dalam identifikasi antigen yang berpotensi dan berguna untuk membantu mendiagnosis TB paru. Antigen tersebut disandi 
oleh gen Regions of Differences (RD) 1-3. Gen RD1-RD3 tidak didapatkan pada M. bovis Bacillus Calmette-Guerin (BCG) sehingga gen RD1-RD3 berperan sebagai gen virulensi yang dimiliki oleh M. tuberculosis. Gen RD1-RD3 menyandi protein early secretory antigenic target protein 6-kDa (ESAT-6), culture filtrate protein 10-kDa (CFP-10), dan M. tuberculosis protein 64 (MPT64) $\cdot^{1-5}$

Pada individu yang terinfeksi $M$. tuberculosis, terbentuk respons imun alamiah yang menyebabkan M. tuberculosis akan difagosit oleh makrofag dan dendritic cell (DC). Mycobacterium tuberculosis menyekresi protein ESAT-6, CFP10, dan MPT-64 yang berperan sebagai faktor virulensi sehingga $M$. tuberculosis dapat bertahan hidup serta bereplikasi di dalam makrofag dan DC. Protein ESAT-6 dan CFP-10 menyebabkan lisisnya makrofag dan DC sehingga M. tuberculosis dapat menyebar dan protein-protein ini dapat ditemukan dalam sputum, serum, dan cairan tubuh lainnya. Ditemukannya antigen ESAT-6, CFP-10, dan MPT-64 pada bahan pemeriksaan sputum, serum, urine, dan cairan tubuh lain menandakan pada individu tersebut terdapat $M$. tuberculosis hidup. ${ }^{4,14}$

Pemeriksaan imunoserologi berdasar atas deteksi complex specific cocktail antigen Mycobacterium tuberculosis ESAT-6, CFP-10, dan MPT-64 (untuk selanjutnya disebut cocktail antigen TB) pada berbagai bahan pemeriksaan menggunakan antibodi spesifik telah banyak dikembangkan. Bahan pemeriksaan yang dapat dipakai adalah sputum, serum, urine, dan cairan tubuh lain. ${ }^{6-8}$ Saat ini terdapat pemeriksaan imunoserologi untuk mendeteksi cocktail antigen TB dengan menggunakan metode rapid immunochromatography (ICT). ${ }^{1,9}$ Shen $\mathrm{dkk}^{10}$ menggunakan kombinasi monoklonal antibodi ESAT-6 dan CFP-10 metode rapid ICT untuk deteksi antigen ESAT-6, dan CFP-10 dari bahan pemeriksaan culture filtrate, didapatkan nilai sensitivitas $97 \%$ dan nilai spesifisitas $97,4 \%$ terhadap baku emas kultur TB pada media cair. ${ }^{11}$

Kalra dkk. ${ }^{1}$ pada tahun 2010 menggunakan kombinasi monoklonal antibodi ESAT-6, CFP-10, dan MPT-64 metode enzyme linked immunoassay (ELISA) untuk deteksi cocktail antigen TB dari bahan pemeriksaan serum penderita TB paru didapatkan nilai sensitivitas $95 \%$ dan nilai spesifisitas 95\% terhadap baku emas kultur TB pada media cair. Gustiani dkk. ${ }^{12}$ melakukan uji validitas complex specific cocktail antigen $M$. tuberculosis (ESAT-6, CFP-10, MPT-64) metode rapid ICT dengan bahan pemeriksaan sputum penderita TB paru, mendapatkan sensitivitas
95,9\% dan spesifisitas $87,2 \%$ terhadap baku emas kultur TB pada media Ogawa.

Penderita sering kali mengalami kesulitan mengeluarkan sputum dengan kualitas yang baik. Selain itu, terdapat 30\% penderita TB paru yang tidak dapat memproduksi sputum. ${ }^{8}$ Oleh karenanya, perlu dipikirkan alternatif bahan pemeriksaan selain sputum, misalnya serum. Kelebihan serum dalam hal deteksi cocktail antigen TB dibanding dengan sputum adalah cocktail antigen TB disekresikan terus menenerus sebagai faktor virulensi dan pertahanan $M$. tuberculosis terhadap sistem imun sehingga deteksi cocktail antigen TB dalam serum tidak bergantung pada ketersediaan serum (tidak perlu ada tuberkel yang pecah). Pada sputum, BTA dan cocktail antigen TB baru ditemukan dalam sputum setelah ada tuberkel yang pecah. Selain itu, pada penderita TB biasanya dilakukan pemeriksaan laju endap darah dan enzim hati menggunakan bahan pemeriksaan darah atau serum. ${ }^{4}$ Bahan pemeriksaan serum sisa dapat digunakan untuk pemeriksaan cocktail antigen TB metode rapid ICT.

Berlandas pada uraian tersebut di atas dan diperkuat dengan kenyataan bahwa belum terdapat penelitian mengenai cocktail antigen TB dari bahan pemeriksaan sputum dan serum yang berasal dari penderita yang sama di RSUP Dr. Hasan Sadikin Bandung maka peneliti tertarik mengetahui gambaran validitas pemeriksaan complex specific cocktail antigen Mycobacterium tuberculosis (ESAT-6, CFP-10, dan MPT-64) metode rapid ICT sputum dan serum penderita TB paru terhadap baku emas kultur dengan media Ogawa. Penelitian ini menggunakan bahan pemeriksaan sputum dan serum yang berasal dari kelompok kultur sputum M. tuberculosis positif dan negatif. Pada penelitian ini diharapkan nilai sensitivitas dan spesifisitas bahan pemeriksaan serum lebih tinggi daripada nilai sensitivitas dan spesifisitas bahan pemeriksaan sputum sehingga klinisi dapat memilih menggunakan bahan pemeriksaan serum terutama pada penderita yang tidak dapat mengeluarkan sputum.

\section{Metode}

Pengumpulan bahan penelitian ini dilakukan periode Juli 2014 sampai Oktober 2014. Subjek penelitian adalah penderita yang datang berobat ke Poliklinik Pulmonologi atau Poliklinik DOTS RSUP Dr. Hasan Sadikin Bandung, telah didiagnosis oleh klinisi sebagai penderita tuberkulosis paru berdasar standar diagnosis 
International Standard of Tuberculosis Care (ISTC), serta bersedia ikut serta dalam penelitian dengan menandatangani persetujuan (informed consent) sesudah diberi penjelasan. Penelitian ini menggunakan bahan pemeriksaan sputum dan serum dari kelompok kultur sputum $M$. tuberculosis positif dan negatif. Kelompok kultur M. tuberculosis positif diambil dari BBT serum penelitian berjudul "validitas complex specific cocktail antigen $M$. tuberculosis (ESAT-6, CFP10, MPT-64) metode rapid ICT dengan bahan pemeriksaan sputum penderita TB paru". ${ }^{12}$

Kriteria inklusi penelitian ini adalah penderita yang telah didiagnosis TB paru dengan kelompok hasil kultur sputum M. tuberculosis positif maupun negatif dan belum mendapat OAT. Bentuk penelitian adalah observasional deskriptif khusus dengan rancangan penelitian cross sectional, yaitu gambaran validitas pemeriksaan complex specific cocktail antigen M. tuberculosis (ESAT-6. CFP-10, dan MPT-64) metode rapid ICT bahan pemeriksaan sputum memakai serum penderita TB paru dengan baku emas kultur media Ogawa.

\section{Hasil}

Penelitian dilakukan sejak bulan Juli 2014 sampai Oktober 2014. Pada penelitian ini didapatkan 68 subjek penelitian. Hasil penelitian didapatkan 31 kultur sputum positif yang berasal dari (bahan biologi tersimpan) BBT, terdiri atas 29 sampel merupakan M. tuberculosis dan 2 sampel merupakan Mycobacterium other than Tuberculosis (MOTT). Untuk mendapatkan kultur sputum negatif, peneliti mencari dari subjek penelitian yang baru, didapatkan 40 subjek penelitian TB paru. Bahan pemeriksaan sputum dari 40 subjek ini dilakukan kultur pada media Ogawa, didapatkan 4 sampel merupakan M. tuberculosis, 1 sampel MOTT, dan 35 sampel kultur negatif. Total kultur MOTT sebanyak 3 sampel dieksklusi dari penelitian ini. Bahan pemeriksaan sputum dan serum dari 33 kultur sputum M. tuberculosis positif dan 35 kultur $M$. tuberculosis negatif dianalisis sesuai dengan tujuan penelitian ini, yaitu gambaran validitas pemeriksaan cocktail antigen TB metode rapid ICT antara bahan pemeriksaan sputum dan serum penderita TB paru.

Tabel 1 menunjukkan pemeriksaan cocktail antigen TB rapid ICT antara observer 1 dan observer 2 didapatkan index $\kappa$ sebesar 1,0. Index $\kappa$ antara observer 2 dan observer 3 sebesar 1,0 dan antara observer 1 dan observer 3 sebesar 1,0 dengan $p=0,001(p<0,05$ bermakna). Pada prapenelitian didapatkan kesesuaian yang tinggi di antara observer dalam menilai pemeriksaan cocktail antigen TB rapid ICT secara kualitatif, tidak ada keraguan atas pembacaan hasil, dan menghilangkan faktor subjektivitas.

Berdasar Tabel 2, angka positivitas tertinggi pemeriksaan cocktail antigen TB rapid ICT menggunakan bahan pemeriksaan sputum, yaitu $54 \%(37 / 68)$ dan hasil uji statistik dengan tes chi-square menunjukkan perbedaan bermakna hasil angka positivitas pemeriksaan cocktail antigen TB rapid ICT dari bahan pemeriksaan sputum dibanding dengan cocktail antigen TB rapid ICT serum pada nilai $\mathrm{p}<0,001(\mathrm{p} \leq 0,05)$. Pada penelitian ini didapatkan hasil pemeriksaan cocktail antigen TB serum tidak ada yang positif. Didapatkan hasil sensitivitas dan spesifisitas pemeriksaan cocktail antigen TB metode rapid ICT pada sputum adalah $93,9 \%$ dan $82,8 \%$.

Didapatkan hasil sensitivitas dan spesifisitas pemeriksaan cocktail antigen TB dengan metode rapid ICT serum tanpa pemanasan adalah $0 \%$ dan 100\%. Didapatkan hasil sensitivitas dan spesifisitas pemeriksaan cocktail antigen TB metode rapid ICT serum dengan pemanasan adalah $24,2 \%$ dan $85,7 \%$. Tabel 6 menunjukkan gambaran validitas pemeriksaan cocktail antigen TB metode rapid ICT sputum, serum tanpa pemanasan, dan serum dengan pemanasan.

\section{Pembahasan}

Sepanjang penelusuran kepustakaan, penelitian ini merupakan penelitian pertama yang meneliti mengenai gambaran validitas pada pemeriksaan cocktail antigen TB rapid ICT antara bahan

Tabel 1 Kesesuaian Pengujian Interobserver Pemeriksaan Cocktail Antigen TB

\begin{tabular}{|c|c|c|c|c|c|c|}
\hline \multirow{2}{*}{ Variabel } & \multicolumn{2}{|c|}{ Obs 1 vs Obs 2} & \multicolumn{2}{|c|}{ Obs 1 vs Obs 3} & \multicolumn{2}{|c|}{ Obs 2 vs Obs 3} \\
\hline & $\kappa$ & Nilai p & $\boldsymbol{\kappa}$ & Nilai p & $\kappa$ & Nilai p \\
\hline $\begin{array}{l}\text { Cocktail Antigen TB rapid ICT } \\
(\mathrm{n}=30)\end{array}$ & 1,0 & $<0,001$ & 1,0 & $<0,001$ & 1,0 & $<0,001$ \\
\hline
\end{tabular}

Keterangan: $\kappa>0,74$ (excellent agreement) 
Tabel 2 Hasil Angka Positivitas Pemeriksaan Cocktail Antigen TB Rapid ICT (n=68)

\begin{tabular}{lccc}
\hline \multirow{2}{*}{ Pemeriksaan } & \multicolumn{2}{c}{ Angka Positivitas } & Nilai $^{*}$ ) \\
\cline { 2 - 4 } & $\mathbf{n}$ & $\mathbf{\%}$ & \\
\hline Cocktail antigen TB rapid ICT sputum & 37 & 54,4 & $<0,001$ \\
Cocktail antigen TB rapid ICT serum & 0 & 0 & \\
\hline
\end{tabular}

${ }^{*}$ chi square test

Tabel 3 Validitas Pemeriksaan Cocktail Antigen TB Metode Rapid ICT Sputum Penderita TB Paru terhadap Baku Emas Kultur Ogawa

\begin{tabular}{llccc}
\hline & & \multicolumn{2}{c}{ Kultur sputum M. tuberculosis pada Media Ogawa } \\
& & Positif & Negatif & Total \\
\hline $\begin{array}{l}\text { Cocktail antigen TB rapid ICT } \\
\text { (sputum) }\end{array}$ & Positif & 31 & 6 & 37 \\
& Negatif & 2 & 29 & 31 \\
\cline { 2 - 5 } & Total & 33 & 35 & 68 \\
\hline
\end{tabular}

pemeriksaan sputum dan serum penderita TB paru yang sama. Saat ini sputum merupakan bahan pemeriksaan utama dalam menegakkan diagnosis TB paru, namun sputum memiliki kelemahan antara lain terdapat 30\% penderita TB paru yang tidak dapat memproduksi sputum sehingga dapat menyebabkan pemeriksaan mikroskopik BTA maupun kutur $M$. tuberculosis memberikan hasil negatif palsu. Sputum yang berisi BTA baru dikeluarkan apabila terdapat tuberkel atau granuloma yang pecah. ${ }^{8}$ Bahan pemeriksaan serum tidak perlu ada tuberkel yang pecah karena $M$. tuberculosis menyekresi cocktail antigen TB pada saat replikasi dan secara terus menenerus sebagai bagian dari proses pertahanan bakteri terhadap sistem imun. ${ }^{1}$

Pada penelitian ini validitas pemeriksaan cocktail antigen TB metode rapid ICT sputum penderita TB paru terhadap baku emas kultur Ogawa didapatkan sensitivitas 93,9\% serta spesifisitas 82,8\%. Hasil yang didapat ini sedikit berbeda dengan penelitian oleh Gustiani dkk. $^{12}$ di Bandung yang mendapatkan nilai sensitivitas 95,9\% dan spesifisitas sebesar 87,2\%. Berdasar atas Tabel 3 didapatkan 2 dari 33 bahan pemeriksaan sputum memberikan hasil cocktail antigen TB rapid ICT negatif pada kelompok kultur sputum $M$. tuberculosis positif. Pemeriksaan mikroskopik BTA dari kedua spesimen ini negatif. Kemungkinan keadaan ini merupakan negatif palsu dari pemeriksaan cocktail antigen TB rapid ICT yang memengaruhi nilai sensitivitas. Beberapa kemungkinan yang menyebabkan hasil negatif palsu pada penelitian ini adalah rapid ICT tidak dapat mendeteksi kadar cocktail antigen TB dalam sputum. Kemungkinan dalam kedua spesimen ini terkandung cocktail antigen TB, namun tidak terdeteksi karena kadarnya di bawah nilai deteksi minimal rapid ICT. Pemeriksaan rapid ICT mempunyai batas

Tabel 4 Validitas Pemeriksaan Cocktail Antigen TB Metode Rapid ICT Serum Tanpa Pemanasan Penderita TB Paru terhadap Baku Emas Kultur Ogawa

\begin{tabular}{|c|c|c|c|c|}
\hline & & \multicolumn{3}{|c|}{ Kultur Sputum M. tuberculosis pada media Ogawa } \\
\hline \multirow{4}{*}{$\begin{array}{l}\text { Cocktail antigen TB rapid ICT } \\
\text { (serum tanpa pemanasan) }\end{array}$} & & Positif & Negatif & Total \\
\hline & Positif & 0 & 0 & 0 \\
\hline & Negatif & 33 & 35 & 68 \\
\hline & Total & 33 & 35 & 68 \\
\hline
\end{tabular}


Tabel 5 Validitas Pemeriksaan Cocktail Antigen TB Metode Rapid ICT Serum dengan Pemanasan Penderita TB Paru terhadap Baku Emas Kultur Ogawa

\begin{tabular}{lcccc}
\hline & & \multicolumn{2}{c}{ Kultur sputum M. tuberculosis pada Media Ogawa } \\
& & Positif & Negatif & Total \\
\hline Cocktail antigen TB rapid ICT & Positif & 8 & 5 & 13 \\
(serum dengan pemanasan) & Negatif & 25 & 30 & 55 \\
\cline { 3 - 5 } & Total & 33 & 35 & 68 \\
\hline
\end{tabular}

deteksi minimal kadar cocktail antigen TB yang akan memberikan hasil positif, namun pada kit insert rapid ICT yang dipakai dalam penelitian ini tidak mencantumkan berapa batas deteksi minimalnya.

Berdasar atas Tabel 3 pada penelitian ini didapatkan 6 dari 35 bahan pemeriksaan sputum memberikan hasil cocktail antigen TB rapid ICT positif pada kelompok kultur sputum $M$. tuberculosis negatif. Kemungkinan keadaan ini merupakan negatif palsu dari kultur $M$. tuberculosis atau positif palsu dari pemeriksaan cocktail antigen TB rapid ICT yang memengaruhi nilai spesifisitas. World Health Organization masih merekomendasikan penggunaan metode kultur untuk dipergunakan sebagai baku emas dalam mendeteksi M. tuberculosis, walaupun metode ini mempunyai kelemahan karena kultur adalah baku emas yang tidak sempurna (imperfect gold standard). Pemeriksaan kultur Ogawa memerlukan jumlah minimal BTA $10^{1}$ $10^{2}$ organisme $/ \mathrm{mL}$ yang diperlukan untuk dapat menghasilkan kultur yang positif. ${ }^{19}$ Hasil positif palsu dari pemeriksaan cocktail antigen TB rapid ICT dapat terjadi bila terjadi reaksi silang dengan MOTT yang memiliki gen penyandi ESAT-6 like protein dan CFP-10 like protein. Organisme ini antara lain M. kansasii, M. szulgai, M. gastri, M. flavescens, dan M. smegmatis. Pada penelitian oleh Shen dkk. ${ }^{10}$ menemukan M. kansasii pada 17 hasil kultur dari bahan pemeriksaan sputum. Dari 17 kultur dengan M. kansasii hanya 1 yang memberikan hasil pemeriksaan cocktail antigen TB rapid ICT positif. Kultur dengan pertumbuhan MOTT pada penelitian ini dieksklusi sehingga kemungkinan penyebab 6 dari 30 bahan pemeriksaan sputum yang memberikan hasil cocktail antigen TB rapid ICT positif, namun pada kultur sputum $M$. tuberculosis hasilnya negatif karena jumlah minimal BTA dalam spesimen tersebut di bawah $10^{1}-10^{2}$ organisme $/ \mathrm{mL}$.

Validitas pemeriksaan cocktail antigen TB metode rapid ICT serum tanpa pemanasan terhadap baku emas kultur Ogawa didapatkan sensitivitas $0 \%$ dan juga spesifisitas 100\%. Berdasar atas Tabel 4 didapatkan 0 dari 33 bahan pemeriksaan serum tanpa pemanasan memberikan hasil cocktail antigen $\mathrm{TB}$ rapid ICT positif pada kelompok kultur sputum $M$. tuberculosis positif. Hal ini disebabkan cocktail antigen TB membentuk kompleks antigenantibodi. Kompleks antigen-antibodi ini tidak dapat diikat oleh antibodi monoklonal yang terdapat dalam strip pemeriksaan rapid ICT. Kemungkinan lain adalah cocktail antigen TB bebas di dalam serum kadarnya di bawah nilai

Tabel 6 Validitas Pemeriksaan Cocktail Antigen TB Metode Rapid ICT antara Sputum, Serum Tanpa Pemanasan, dan Serum Dengan Pemanasan terhadap Baku Emas Kultur Media Ogawa

\begin{tabular}{lccc}
\hline \multicolumn{1}{c}{ Validitas } & Sputum & $\begin{array}{c}\text { Serum tanpa } \\
\text { Pemanasan }\end{array}$ & $\begin{array}{c}\text { Serum dengan } \\
\text { Pemanasan }\end{array}$ \\
\hline Sensitivitas (\%) & 93,9 & 0 & 24,2 \\
Spesifisitas (\%) & 82,8 & 100 & 85,7 \\
Nilai duga positif (\%) & 83,7 & 0 & 61,5 \\
Nilai duga negatif (\%) & 93,5 & 51,5 & 54,5 \\
Akurasi (\%) & 88,2 & 51,4 & 55,8 \\
\hline
\end{tabular}


batas deteksi rapid ICT karena terencerkan di dalam serum. Berdasar atas Tabel 4 didapatkan 35 dari 35 bahan pemeriksaan serum tanpa pemanasan memberikan hasil cocktail antigen TB rapid ICT negatif pada kelompok kultur sputum M. tuberculosis negatif.

Validitas pemeriksaan cocktail antigen TB metode rapid ICT serum dengan pemanasan terhadap baku emas kultur Ogawa didapatkan sensitivitas 24,2\% dan spesifisitas $85,7 \%$. Penelitian Kalra dkk. ${ }^{1}$ menggunakan kombinasi antibodi monoklonal ESAT-6, CFP-10, dan MPT-64 metode enzyme linked immunoassay (ELISA) untuk deteksi cocktail antigen TB serum penderita TB paru didapatkan nilai sensitivitas 95\% dan spesifisitas 95\% terhadap baku emas kultur TB. ${ }^{1}$ Perbedaan nilai sensitivitas dan spesifisitas antara kedua penelitian ini dipengaruhi penggunaan metode yang berbeda dalam mendeteksi cocktail antigen TB dalam serum.

Berdasar atas Tabel 5 didapatkan 8 dari 33 bahan pemeriksaan serum dengan pemanasan memberikan hasil cocktail antigen TB rapid ICT positif pada kelompok kultur sputum $M$. tuberculosis positif. Pemanasan serum berfungsi melepaskan ikatan kompleks antigen-antibodi dan inaktivasi antibodi sehingga tidak mengikat cocktail antigen TB yang belum berikatan. Pemanasan pada suhu $56^{\circ} \mathrm{C}$ selama 30 menit dapat menyebabkan denaturasi protein selain immunoglobulin dalam serum menyebabkan hasil positif palsu. Peneliti sudah melakukan pemeriksaan cocktail antigen TB rapid ICT serum sepuluh subjek penelitian yang sehat sebagai kontrol negatif. Hasil pemeriksaan ini pada serum tanpa pemanasan maupun dengan pemanasan negatif. Kemungkinan hasil positif palsu akibat denaturasi protein karena pemanasan dapat disingkirkan.1

Berdasarkan Tabel 5 telah didapatkan 25 dari 33 bahan pemeriksaan serum dengan pemanasan memberikan hasil cocktail antigen TB rapid ICT negatif pada kelompok kultur sputum M. tuberculosis positif. Kemungkinan keadaan ini merupakan negatif palsu dari pemeriksaan cocktail antigen TB rapid ICT yang mempengaruhi nilai sensitivitas. Hasil negatif palsu pada penelitian ini kemungkinan dapat terjadi karena rendahnya kadar cocktail antigen TB dalam serum yang dapat terdeteksi oleh rapid ICT karena antigen dalam serum terencerkan. ${ }^{1}$ Sama seperti bahan pemeriksaan sputum, kemungkinan penyebab hasil negatif palsu pada penelitian ini adalah baku emas kultur yang tidak sempurna (imperfect gold standard). ${ }^{1}$
Nilai duga positif pemeriksaan cocktail antigen TB rapid ICT dari sputum adalah $83,7 \%$. Nilai duga positif adalah kemungkinan seseorang benar-benar menderita penyakit bila hasil pemeriksaannya positif. Nilai duga negatif pemeriksaan ini adalah $93,5 \%$. Nilai duga negatif adalah kemungkinan seseorang tidak menderita penyakit bila hasil pemeriksaannya negatif. Nilai duga negatif pada penelitian ini tinggi sehingga untuk bahan pemeriksaan sputum dapat digunakan untuk "rule out" diagnosis TB paru. Akurasi pemeriksaan ini untuk bahan pemeriksaan sputum adalah $88,2 \%$. Akurasi adalah nilai yang menggambarkan ketepatan dalam memprediksi kemungkinan seseorang menderita atau tidak menderita suatu penyakit.

Nilai duga positif pemeriksaan cocktail antigen TB rapid ICT serum degan pemanasan adalah $61,5 \%$. Nilai duga positif adalah kemungkinan seseorang benar-benar menderita penyakit bila hasil pemeriksaannya positif. Nilai duga negatif pemeriksaan ini adalah 54,5\%. Nilai duga negatif adalah kemungkinan seseorang tidak menderita penyakit bila hasil pemeriksaannya negatif. Nilai duga negatif pada penelitian ini rendah sehingga pemeriksaan cocktail antigen TB rapid ICT tidak dapat digunakan untuk "rule out" diagnosis TB paru. Akurasi pemeriksaan ini untuk bahan pemeriksaan serum dengan pemanasan adalah $55,8 \%$.

Suatu alat pemeriksaan untuk mendiagnosis diharapkan mempunyai uji diagnostik yang ideal. Alat diagnostik diharapkan mempunyai sensitivitas dan spesifisitas yang tinggi, tetapi uji diagnostik yang ideal jarang sekali ditemukan. Pada penelitian ini untuk bahan pemeriksaan sputum nilai sensitivitasnya lebih tinggi apabila dibanding dengan nilai spesifisitasnya sehingga pemeriksaan ini dapat digunakan untuk skrining pada populasi penderita TB paru. Untuk bahan pemeriksaan serum nilai spesifisitasnya lebih tinggi dibanding dengan nilai sensitivitasnya, sehingga pemeriksaan ini dapat digunakan untuk konfirmasi diagnosis TB paru.

Penelitian ini masih mempunyai beberapa keterbatasan di antaranya adalah penggunaan kultur M. tuberculosis sebagai baku emas tidak sempurna (imperfect gold standard atau allowed gold standard) karena bila hasil kultur $M$. tuberculosis negatif tidak dapat menyingkirkan diagnosis TB paru bila klinis dan pemeriksaan lainnya menunjang.

Simpulan, pemeriksaan cocktail antigen TB metode rapid ICT pada bahan pemeriksaan sputum memiliki nilai sensitivitas tinggi dan spesifisitas sedang. Pemeriksaan cocktail antigen 
TB metode rapid ICT pada bahan pemeriksaan serum mempunyai nilai sensitivitas rendah dan juga spesifisitas tinggi. Penggunaan bahan pemeriksaan serum untuk deteksi cocktail antigen TB masih memerlukan penelitian lebih lanjut.

\section{Daftar Pustaka}

1. Kalra M, Khuller G, Grover A, Behera D, Wanchu A, Verma I. Utility of a combination of RD1 and RD2 antigens as a diagnostic marker for tuberculosis. Diag Microbiol Infect Dis. 2010;66(2):153-61.

2. Kleinnijenhuis J, Oosting M, Joosten L, Netea $\mathrm{M}$, Crevel RV. Innate immune recognition of Mycobacterium tuberculosis. Clin Dev Immunol. 2011;2011:405310.

3. Maurya A, Nag V, Kant S, Kushwaha R, Kumar M, Mishra V. Evaluation of an immunochromatographic test for discrimination between Mycobacterium tuberculosis complex \& non tuberculous mycobacteria in clinical isolates from extrapulmonary tuberculosis. Indian J Med Res. 2012;135(6):901-6.

4. Lightbody K, Ilghari D, Waters L, Carey G, Bailey M, Williamson R. Molecular features governing the stability and specificity of functional complex formation by Mycobacterium tuberculosis CFP-10/ ESAT-6 family proteins. J Biol Chem. 2008; 283(25):17681-90.

5. Ganguly N, Siddiqui I, Sharma P. Role of M. tuberculosis RD-1 region encoded secretory proteins in protective response and virulence. Tuberculosis (Edinb). 2008; 88(6):510-7.

6. Feng T, Shou C, Shen L, Qian Y, Wu Z, Fan J. Novel monoclonal antibodies to ESAT- 6 and CFP-10 antigens for ELISA-based diagnosis of pleural tuberculosis. Int J Tuberc Lung Dis.
2011;15(6):804-10.

7. Song F, Sun X, Wang X, Nai Y, Liu Z. Early diagnosis of tuberculous meningitis by an indirectELISA protocolbased on the detection of the antigen ESAT-6 in cerebrospinal fluid. Irish J Med Sci. 2014;183(1):85-8.

8. Kashyap R, Ramteke S, Morey S, Purohit H, Taori G, Daginawala H. Diagnostic value of early secreted antigenic target- 6 for the diagnosis of tuberculous meningitis patients. Infection. 2009;37(6):508-13.

9. Toihir A, Rasolofo V, Andrianarisoa S, Ranjalahy G, Ramarokoto H. Validation of an immunochromatographic assay kit for the identification of the Mycobacterium tuberculosis complex. Memorias do Instituto Oswaldo Cruz. 2011;106(6):777-80.

10. Shen G, Chiou C, Hu S, Wu K, Chen J. Rapid identification of the Mycobacterium tuberculosis complex by combining the ESAT-6/CFP-10 immunochromatographic assay and smear morphology. J Clin Immunol. 2011;49(3):902.

11. Azzurri A, Kanaujia G, Sow O, Bah B, Diallo A, Prete GD. Serological markers of pulmonary tuberculosis and of response to anti-tuberculosis treatment in a patient population in Guinea. Int J Immunopathol Pharmacol. 2006;19(1):199-208.

12. Gustiani N, Parwati I, Tjandrawati A, Lismayanti L. Validitas pemeriksaan complex specific antigen Mycobacterium tuberculosis RD1-RD3 (antigen ESAT6, CFP10, dan MPT64) metode rapid immunochromatography pada sputum penderita tuberkulosis paru. MKB. 2014;46 (4):241-6.

13. Hadi N, Kabiri M. Detection of Mycobacterial antigen and antibody in patients with tuberculosis and their association with therapy. Iranian Red Crecscent Soc 2007; 9:74-9. 